\title{
Forensic reconstruction of Ictalurus punctatus invasion routes using on-line fishermen records
}

\author{
Filipe Banha ${ }^{1, *}$, Ana Veríssimo ${ }^{2,3}$, Filipe Ribeiro ${ }^{4}$ and Pedro M. Anastácio ${ }^{1}$ \\ ${ }^{1}$ MARE - Marine and Environmental Sciences Centre, Departamento de Paisagem, Ambiente e Ordenamento, Escola de Ciências \\ e Tecnologia, Universidade de Évora, Évora, Portugal \\ ${ }^{2}$ CIBIO-U.P., Centro de Investigação em Biodiversidade e Recursos Genéticos, Vairão, Portugal \\ ${ }^{3}$ Virginia Institute of Marine Science, College of William and Mary, Gloucester Point, VA, USA \\ ${ }^{4}$ MARE - Marine and Environmental Sciences Centre, Faculdade de Ciências, Universidade de Lisboa, Campo Grande, Lisboa, \\ Portugal
}

\begin{abstract}
In this work, the presence of the channel catfish Ictalurus punctatus in the Portuguese section of the Guadiana drainage (Iberian Peninsula) is confirmed based on morphological and molecular species identification. The spatial and temporal dispersal of this non-native catfish was also reconstructed for the Guadiana drainage, based mostly on online fishermen records with minor contributions from the few scientific reports available. The obtained records (mainly from angling fora) span the period since the species' first reported presence in Iberia (1980s) up to the present, and support a westward invasion pattern of non-native fish (NNF) reported for the Iberian fish invasion hotspot. The invasion pathway is driven mainly by natural dispersal downstream at a rate between 8 and $42 \mathrm{~km}$ per year. Yet, at least four introduction events within the Guadiana drainage can unambiguously be assigned to human translocations after the initial human-mediated introduction. The present study reinforces the usefulness and relevance of using validated on-line fishermen records, provides a more complete and updated distribution range of NNF species and enables assessment of their dispersal patterns. This is of particular importance because it allows near realtime monitoring of NNF dispersal, including first occurrences of NNF, at minimal cost.
\end{abstract}

Keywords: dispersal / channel catfish / portugal / non-native fish / distribution

Résumé - Reconstruction scientifique des voies d'invasion d'Ictalurus punctatus à l'aide d'articles en ligne de pêcheurs. Dans ce travail, la présence du poisson-chat Ictalurus punctatus dans la partie portugaise du bassin hydrographique du Guadiana (Péninsule Ibérique) est confirmée sur la base de l'identification morphologique et moléculaire de l'espèce. La dispersion spatiale et temporelle de ce poisson-chat non indigène a également été reconstituée pour le bassin du Guadiana, en se basant principalement sur des articles en ligne de pêcheurs, avec des contributions mineures provenant des quelques rapports scientifiques disponibles. Les enregistrements obtenus (principalement à partir de forums de pêche à la ligne) couvrent la période depuis la première présence signalée de l'espèce en Péninsule Ibérique (1980) jusqu' à aujourd'hui, et confirment un schéma d'invasion vers l'ouest des poissons non indigènes (NNF) signalé par le hotspot d'invasion des poissons ibériques. La voie d'invasion est faite principalement par la dispersion naturelle en aval, à un rythme de 8 à $42 \mathrm{~km}$ par année. Cependant, au moins quatre événements d'introduction dans le bassin hydrographique du Guadiana peuvent être attribués sans ambiguïté à des translocations humaines après l'introduction initiale par l'homme. La présente étude renforce l'utilité et la pertinence d'utiliser des informations en ligne validées de pêcheurs, afin de fournir une carte de distribution plus complète et mise à jour des espèces de poissons non indigènes et d'évaluer leurs modèles d'invasions. Ceci est d'une importance particulière, car il permet une surveillance quasi en temps réel de la dispersion des $\mathrm{NNF}$, y compris les premières occurrences de $\mathrm{NNF}$, et ce, presque gratuitement.

Mots-clés : dispersion / poisson-chat / portugal / poisson non indigène / distribution

\footnotetext{
*Corresponding author: filipebanha@hotmail.com
} 


\section{Introduction}

Non-native species are a leading threat to aquatic biodiversity worldwide (Sala et al., 2000), and to freshwater fishes in particular (Moyle and Light, 1996). The main vectors of non-native fish (NNF) introductions are aquaculture, recreational fisheries and ornamental fish trade (Welcomme, 1988; Gozlan et al., 2010), although the importance of these vectors varies geographically. For instance, while aquaculture and waterways are the main reasons for NNF introduction and establishment in central Europe, recreational fisheries are the predominant vector in the Iberian Peninsula (Elvira and Almodóvar, 2001; Ribeiro et al., 2009a; Rabitsch et al., 2013). The Iberian Peninsula has been referenced as a fish invasion hotspot (Leprieur et al., 2008), which is of major concern given its large number of endemic species with restricted distributions (Filipe et al., 2009). Indeed, Iberian freshwater ecosystems exhibit a high rate of NNF arrival, with one new species being recorded every two years (Elvira and Almodóvar, 2001; Ribeiro et al., 2009a). In fact, more than five new NNF were identified in this region in the last decade (e.g. Ribeiro and Veríssimo, 2014; Banha et al., 2015), of which many are listed as high impact NNF (e.g. Ribeiro et al., 2015). Despite the high rate of recent NNF introductions in the Iberian Peninsula, little is known about how and where illegal recreational fish introductions occur.

Early detection of non-native species is crucial to minimize the negative impacts of a potential invasion to the recipient ecosystems and to reduce the associated costs of subsequent control/remediation actions (Mehta et al., 2007). Indeed, it has been shown that eradication of invasive species is more difficult following species' establishment and involves increased costs (Simberloff, 2001).

Early detection of NNF can be made using online information about recreational fishermen catches. The use of online fishermen fora is growing at an increasing rate, providing an unparalleled opportunity for improved and "nearreal time" knowledge on recent NNF arrivals (Ribeiro and Veríssimo, 2014; Banha et al., 2015). These records can be posteriorly verified in situ by scientists and/or managers allowing for unambiguous species identification, e.g. via morphological and/or molecular studies, while helping to direct sampling efforts in the field and subsequent monitoring of the species' establishment and control actions. These nonscientific data also have great potential in helping the reconstruction of the spatial invasion patterns of NNF. A recent study in the Iberian Peninsula used records of the nonnative Silurus glanis from online fishermen fora to unveil the progression of this species in the Tagus drainage and provided information about the species' habitat and invasion through time (Gago et al., 2016).

The general spatial invasion pattern of NNF in Iberian Peninsula (i.e. westward invasion) provides a unique opportunity to distinguish human-mediated introductions from natural dispersal (Ribeiro et al., 2009b; Gago et al., 2016). In fact, most NNF Iberian introductions initially occur in Catalonian watersheds (northeastern Iberia), followed by secondary introductions in central Iberia (upper reaches of international rivers), that drain westwards and eventually arrive to the Portuguese section in the lowland areas of international rivers (Ribeiro et al., 2009b). The channel catfish,
Ictalurus punctatus (Rafinesque, 1818) is one such species apparently following this spatial pattern (Hermoso et al., 2008). The species was supposedly firstly introduced in the lower Ebro (northeastern Iberia) in the late 1980s (Doadrio, 2001; Elvira and Almodóvar, 2001; López et al., 2012), but subsequent records were on the mid part of the Guadiana drainage, an international river (Hermoso et al., 2008). Despite this frequent Peninsula-wide spatial invasion pattern, there is little information about NNF dispersal within watersheds, although such knowledge is particularly relevant for the management of international watersheds.

The channel catfish is originally from the eastern United States and northeastern Mexico but has been introduced worldwide, including at least five European countries, mostly for aquaculture and for recreational fisheries (Elvira and Almodóvar, 2001; Uzunova and Zlatanova, 2007; Ligas, 2008; Zogaris et al., 2012). This species is an omnivorous opportunistic feeder but large individuals become piscivorous (Perry Jr., 1969; Cannamela et al., 1978). The channel catfish exhibits parental care (nest guarding), relatively high fecundity, and is tolerant of a wide range of environmental conditions (Tucker and Hargreaves, 2004). It also exhibits high longevity (up to 40 years old) and attains large sizes (over $10 \mathrm{~kg}$ and $1 \mathrm{~m}$ long) (Moyle, 2002). Although the channel catfish may exert a major negative effect on native fishes populations, through competition for food and habitat, or through predation (Marsh and Brooks, 1989; Hawkins and Nesler, 1991; Olden and Poff, 2005), there are no studies that address the ecological impact of the species (Savini et al., 2010).

In this work, the presence of the non-native channel catfish I. punctatus is confirmed for Portugal, using both morphological and molecular species identification. Correct taxonomic identification of NNF is mandatory for a species to be included in the national inventory of non-native species. It is also extremely important in delineating adequate management plans (e.g. Goolsby et al., 2006) and in future monitoring of species' establishment and impact. Additionally, the spatial and temporal invasion of the channel catfish within the Guadiana watershed was reconstructed based on anglers' online records, and the usefulness of this type of approach for invasion pathway reconstruction was demonstrated.

\section{Materials and methods}

\subsection{Confirmation of Ictalurus punctatus presence in Portugal}

On 12 October 2016, a professional fisherman captured ten $I$. punctatus individuals using a $80 \mathrm{~mm}$ mesh gillnet in the Alqueva reservoir $\left(38^{\circ} 11^{\prime} 57.89^{\prime \prime} \mathrm{N} ; 7^{\circ} 29^{\prime} 47.93^{\prime \prime} \mathrm{W}\right)$. The fish were brought to the laboratory for morphological identification following Hubbs et al. (2008) and Paruch (1986), based on meristic features. Total length (TL), fork length (1 mm) and total weight of all specimens were measured to the nearest $1 \mathrm{~mm}$ and $0.01 \mathrm{~g}$. Fishes were dissected to determine the sex and the maturity stage. A fin clip was also collected from each fish and preserved in absolute ethanol for molecular species identification using a fragment of the cytochrome oxidase subunit I (COI) gene. Briefly, genomic DNA (gDNA) was extracted using the EasySpin Genomic DNA Tissue Kit (Citomed, Lisbon, Portugal), following the manufacturer's protocol. A $619 \mathrm{bp}$ 
fragment of the COI was amplified using the Polymerase chain reaction (PCR) and the following primers: FishF2 $5^{\prime}$ TCGACTAATCATAAAGATATCGGCAC 3', and FishR1 $5^{\prime}$ TAGACTTCTGGGTGGCCAAAGAATCA $3^{\prime}$ (Ward et al., 2005). PCR reactions were performed in a total volume of $10 \mu \mathrm{l}$ including $5 \mu \mathrm{l}$ of MyTaqTM HS Mix 2X (Bioline, London, U.K.), $0.4 \mu$ l of each primer $(10 \mu \mathrm{M}), 3.2 \mu \mathrm{l}$ of ultrapure autoclaved water, and $1 \mu \mathrm{l}$ of gDNA. After optimization, the PCR temperature profile included an initial denaturation of $5 \mathrm{~min}$ at $95^{\circ} \mathrm{C}$, followed by 35 cycles of $1 \mathrm{~min}$ at $95^{\circ} \mathrm{C}, 30 \mathrm{~s}$ at $57.2^{\circ} \mathrm{C}, 1 \mathrm{~min}$ at $72^{\circ} \mathrm{C}$ and a final extension step of $10 \mathrm{~min}$ at $72^{\circ} \mathrm{C}$. The amplicons were sequenced at Macrogen Europe (Amsterdam, The Netherlands) and quality control of the resulting sequences was performed in Geneious (Biomatters, 2013). Sequences were aligned using the Geneious algorithm under default conditions and compared to those available in GenBank for other Ictalurus species.

The specimens and respective tissue samples were deposited in the zoological collection "Museu Bocage" of the Museu Nacional de História Natural e da Ciência (MUHNAC; University of Lisbon, Portugal): whole voucher specimen MB05-003527 in the Fish Collection; Tissue and DNA Collection samples MB85-016900 to MB85-016909.

\subsection{Ictalurus punctatus invasion}

Extensive searches on different information sources such as literature, social media websites (e.g. YouTube), recreational fisheries fora and blogs, and news-media channels were consulted to obtain channel catfish I. punctatus records aiming at tracking the invasion pathway and timing within the Guadiana drainage. Following Gago et al. (2016), a Boolean search was performed during October and November 2016 using different combinations of keywords, including common names in Portuguese and Spanish (i.e. peixe-gato; pez gato; pez gato del canal), and the river name (Guadiana). As in previous works (e.g. Gago et al., 2016), confirmed species' records were accepted only when including locality, year and accompanying media (picture or video that allows confirmation of morphometric features of channel catfish such as four pairs of barbels, adipose fin clearly separated from the caudal fin, deeply forked caudal fin). Additionally, only the earliest record was retained when multiple records were reported for the same location in different information sources. The geographical coordinates were extracted from Google Maps, and when a reservoir name was given as locality, the coordinates from the reservoir mid-point were used. The river distance (in $\mathrm{km}$ ) between each pair of records was measured based on satellite photos available in Google Earth $^{\circledR}$ 7.1.7.2606 version using the measure tool. Annual expansion rates within the Guadiana catchment were calculated based on the two most distant records per year.

\section{Results}

\subsection{Confirmation of Ictalurus punctatus presence in Portugal}

The specimens captured in the Portuguese section of the Guadiana watershed had four pairs of barbels, dorsal fin with one spine and six soft rays, pectoral fins with a spine, and naked skin, characteristics of the family Ictaluridae. The specimens also had eyes present, adipose fin clearly separated from the caudal fin, deeply forked caudal fin, assigning them to the genus Ictalurus. The deep caudal fork, the silvery body with dark spots along the dorsal area, anal fin ray counts under 30 (median $=27$, range between 24 and 29), and serrated barbs on the posterior side of the pectoral spine supports their identification as I. punctatus. The individuals captured presented a mean TL of $416 \pm 57 \mathrm{~mm} \mathrm{SD}$ and mean total weight of $646 \pm 286 \mathrm{~g} \mathrm{SD}$. All individuals had undeveloped gonads and thus it was not possible to determine their sex macroscopically.

Molecular analyses provided concordant identification of the specimens as I. punctatus. Of the ten sampled specimens, eight produced good quality COI sequences and the final alignment showed all sequences to be identical (GenBank Accession no. KY471388). BLAST searches showed the above haplotype exhibited $98-99 \%$ similarity (99\% query cover; E-value: 0.0 ) to available I. punctatus sequences from the North American native range (e.g. GenBank Accession nos. JF292392-JF292380; Wong et al., 2011). Other Ictalurus species' entries showed a lower sequence similarity $(<94 \%)$ for the same level of query coverage (i.e. 99\%).

\subsection{Ictalurus punctatus invasion}

A total of 42 records were obtained for channel catfish on the Guadiana river catchment, with the angling fora representing the main source of information with $59 \%$ of all records. A mean of three records per year were registered from 2006 to 2016, with a maximum of 9 records in 2012. Although the number of records grew regularly over the years, the number of locations was stable until 2010, but doubled thereafter (Tab. 1). Almost $50 \%$ of all new records were within a $50 \mathrm{~km}$ distance of previous ones, with the number of records generally decreasing with increasing distance. Records at distances of $50-100 \mathrm{~km}$ represent less than $20 \%$ and from $100 \mathrm{~km}$ to $150 \mathrm{~km}$ only $12 \%$ of total records. However, approximately $25 \%$ of the occurrences were registered at distances over $200 \mathrm{~km}$. Records corresponding to large expansions in the invaded area occurred in two periods: 2010-2011 and 2015-2016, with the addition of nearly $100 \mathrm{~km}$ of river stretch in both cases (Fig. 1).

Reconstruction of the spatial invasion pattern of the channel catfish along the Guadiana River showed that dispersal was mainly downstream, at a rate ranging between 8 and $42 \mathrm{~km}$ per year (Fig. 2). At least four introduction events within the Guadiana drainage can unambiguously be assigned to human assisted introductions because these locations are isolated (by downstream dams) from previously invaded areas. The first record in the Guadiana drainage is from 1983 at Castilseras dam located in a tributary of the Zújar river, based on a catfish anglers' video on Youtube. Subsequent records are from the Zújar and La Serena dams in the 1990s, both located in the Zújar River downstream from the Castilseras dam. These two locations represented $62 \%$ of the records gathered in this work (12 records in Zújar dam and 14 in La Serena dam). The second introduction event occurred during the 1990s at Orellana dam, located in the mainstream of the Guadiana river and with no direct connection to the Zújar river. Thus, the most probable source might be a translocation from the Zújar river $(11 \mathrm{~km}$ by 
Table 1. Number of Ictalurus punctatus records per time period in the River Guadiana drainage between the 1980s and 2016, collected from various information sources: literature (papers and books); angling forums; youtube.com; blogs and other web sources (e.g. tourist promoter's sites, environmental groups, popular science sites, instagram.com, flickr.com, facebook.com).

\begin{tabular}{|c|c|c|c|c|c|c|}
\hline Year & Angler forums & Youtube & Literature & Blogs and others web sources & Total & Number of new locations \\
\hline $80 \mathrm{~s}$ & 0 & 1 & 0 & 0 & 1 & 1 \\
\hline $90 \mathrm{~s}$ & 0 & 0 & 2 & 0 & 2 & 2 \\
\hline 2006 & 1 & 0 & 1 & 0 & 2 & 1 \\
\hline 2007 & 2 & 0 & 0 & 0 & 2 & 0 \\
\hline 2008 & 3 & 0 & 0 & 0 & 3 & 1 \\
\hline 2009 & 1 & 0 & 0 & 0 & 1 & 0 \\
\hline 2010 & 6 & 0 & 0 & 0 & 6 & 1 \\
\hline 2011 & 0 & 1 & 0 & 1 & 2 & 1 \\
\hline 2012 & 5 & 2 & 0 & 2 & 9 & 1 \\
\hline 2013 & 2 & 0 & 0 & 1 & 3 & 0 \\
\hline 2014 & 2 & 1 & 0 & 0 & 3 & 1 \\
\hline 2015 & 2 & 0 & 0 & 1 & 3 & 1 \\
\hline 2016 & 1 & 2 & 1 & 1 & 5 & 2 \\
\hline Total & 25 & 7 & 4 & 6 & 42 & 12 \\
\hline
\end{tabular}

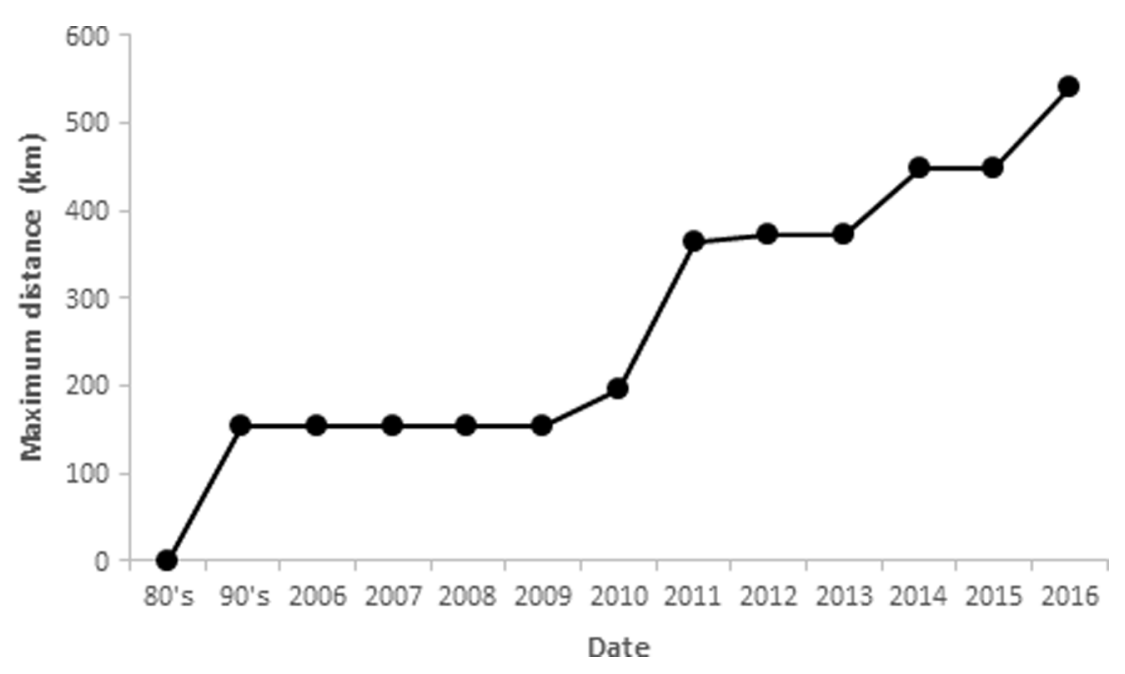

Fig. 1. Maximum river stretch distance $(\mathrm{km})$ invaded by Ictalurus punctatus in the Guadiana river, as a function of time. The invaded river stretch corresponds to the sum of distances between the furthest up- and downstream locations for a given year.

road) or from Castilseras dam $(79 \mathrm{~km}$ by road). The third introduction event occurred around 2010 at the Garcia-Sola dam, located upstream from the Orellana dam but without any fish passage. Finally, the fourth introduction event occurred around 2014 at La Colada dam, a smaller reservoir located upstream from La Serena dam (46 km by road). Downstream natural dispersal from Orellana and Zújar dams occurred along the past decade reaching the upper part of the Alqueva dam in 2011 (e.g. Ajuda bridge) and reaching the lower reaches of the Guadiana (Mértola) in 2016. Currently, the total invaded area covers $541 \mathrm{~km}$ of river stretch in the Guadiana drainage $(337 \mathrm{~km}$ in the main drainage; $41 \%$ of total river length) (Tab. 2).

\section{Discussion}

The current work confirms the presence of the non-native channel catfish I. punctatus in Portugal and documents in detail its spatial invasion pattern within the Guadiana drainage (one of the largest rivers in the Iberian Peninsula). As seen in other freshwater NNF within Iberian waters, the channel catfish showed a progression from a north-eastern entryway via the Ebro drainage, into the central part of the peninsula and the upper reaches of international rivers that flow into the Atlantic (Ribeiro et al., 2009b). Additionally, the present study reinforces the relevance of using online fishermen's records to unveil the invasion patterns of NNF and to provide a more complete and updated distribution range for these species (Ribeiro and Veríssimo, 2014; Banha et al., 2015; Gago et al., 2016). Indeed, online records by anglers suggest that I. punctatus original introduction in Spain occurred in 1983 at Castilseras dam (Almadén), probably before the first record (1987) in the Lower Ebro (López et al., 2012). For the Guadiana drainage, this record at Castilseras dam occurs more than one decade before the first scientific record from the late 1990s (Pérez-Bote, 2006). The 


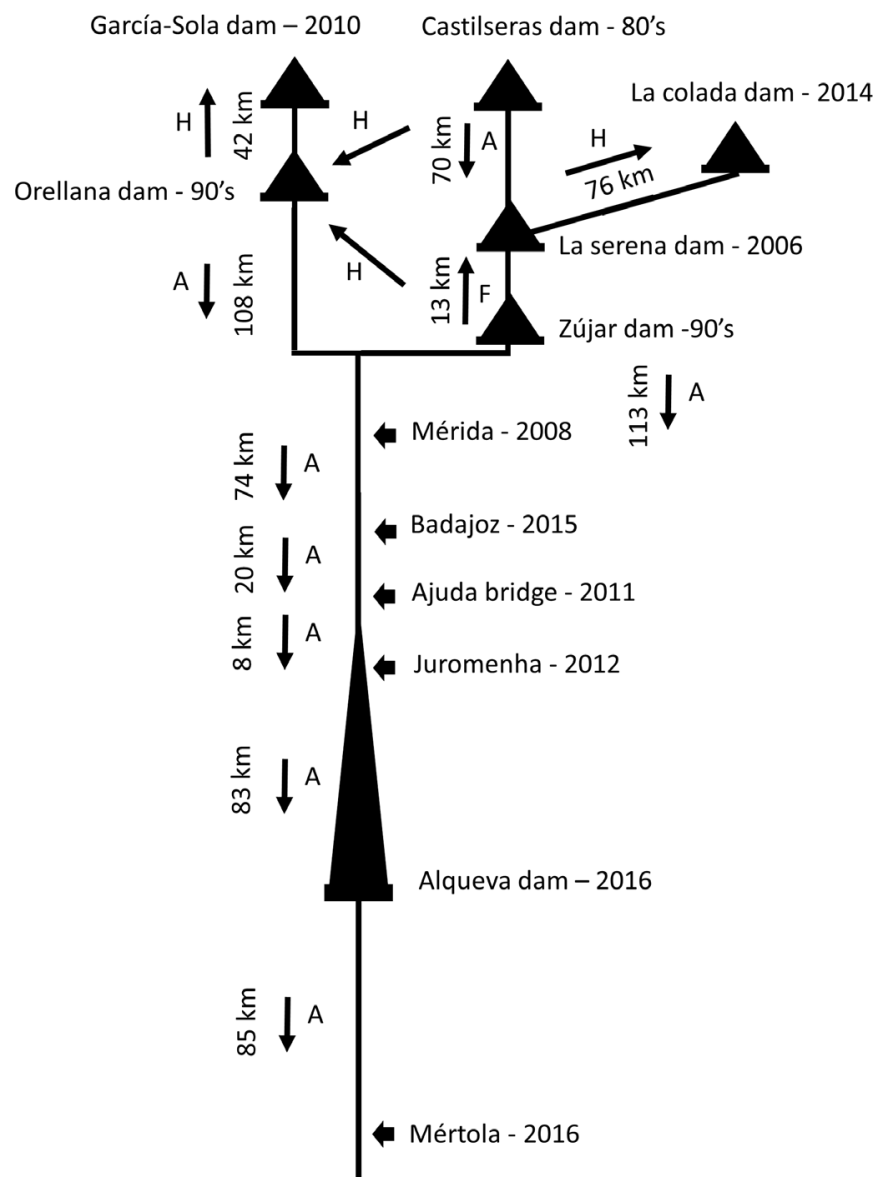

Fig. 2. Forensic reconstruction of Ictalurus punctatus invasion in the Guadiana river drainage, based on online and literature records. Arrows indicate dispersal direction and the associated letter describes the probable means of dispersal (A - active dispersal; $\mathrm{H}$ - human translocation; $\mathrm{F}$ - dam constructed in previously flooded area by a downstream dam). River distance in kilometers between successive locations and year of first detection for each location were given in corresponding stretch of river and location.

usefulness of fishermen records is further augmented by the relative easiness to access both past, and near real-time information on NNF occurrence and dispersal, at minimal cost.

Previous work involving online angler fora records identified three potential sources of bias for this data type. First, bias due lag time between detection by fishermen and online availability (Banha et al., 2015). Second, bias on angler demographics, with higher incidence of information from younger fishermen (e.g. Sax et al., 2003). Third, bias due to omissions for sake of secrecy, prestige, or fear that records may influence the actions of fishery management agencies (Venturelli et al., 2017).

Our forensic reconstruction of I. punctatus invasion in the Guadiana river basin also showed that natural active dispersal downstream is probably the major mechanism of range expansion by this species. The estimated range expansion rate for the channel catfish was between 8 and $42 \mathrm{~km}$ per year according to the time and distance between records. Several studies show that channel catfish have a great dispersal ability: its movement ranges from 0.3 to $1.4 \mathrm{~km} /$ day in ponds
(Ziebell, 1973), while reported downstream and upstream movements in the Minnesota river were $219 \mathrm{~km} / \mathrm{year}$ and $124 \mathrm{~km} /$ year, respectively (Hubley Jr., 1963). The maximum distance moved by specimens of I. punctatus in rivers were $74 \mathrm{~km}$ downstream in 45 days (McCammon, 1956), and $469 \mathrm{~km}$ upstream in 72 days (Dames et al., 1989). Data gathered in this study indicate that reservoirs may provide particularly suitable habitats for catfish populations, since most of the channel catfish records available online were from reservoirs $(88 \%)$. This is not surprising given that these are the areas preferred by recreational fishermen (Marta et al., 2001). Indeed, the large majority of NNF in the Iberian Peninsula occur mainly in lentic habitats (Ribeiro et al., 2009b), although the channel catfish is also well adapted to rivers (Moyle, 2002). Significant habitat alterations that occurred in the Guadiana drainage, e.g. the construction of the largest reservoir in Western Europe (Alqueva reservoir, established in 2002), might have aided the expansion and establishment of the channel catfish in Portugal as suggested for the black bullhead Ameiurus melas (Rafinesque, 1820) by Ribeiro et al. (2006). The specimens collected in Alqueva were 4 to 5 years old (Appelget and Smith Jr., 1951; Sneed, 1951; Tucker and Hargreaves, 2004) and thus were born approximately in 2011 after dam construction, suggesting the establishment of a breeding population locally.

The ecological consequences of the arrival of the channel catfish are unpredictable, but there is potential for a very negative impact on the Guadiana river fish community, given its richness in endemic species (Filipe et al., 2004). Currently, the number of NNF in the lower Guadiana equals the number of native freshwater fish, with eleven species each (Ribeiro et al., 2009a; Filipe et al., 2010). In mainland Portugal, there are $20 \mathrm{NNF}$ including six new species since the last inventory conducted in the late 2000s (Ribeiro et al., 2009a), representing an incredibly fast rate of species introduction and establishment. Such a high establishment rate also raises concerns related to the introduction of other non-native species, particularly species that can accidentally be carried by recreational fishermen (e.g. Procambarus clarkii, Crangonyx pseudogracilis (Banha and Anastácio, 2015) and Dreissena polymorpha larvae (Banha et al., 2016)).

To conclude, we confirm the presence of I. punctatus in Portugal and report the invasion pathway of this non-native freshwater fish, within an international drainage. We demonstrate that the species current distribution within the Guadiana drainage results from multiple independent introductions/translocations coupled to natural downstream dispersal, eventually extending beyond national boundaries. Our approach was based mostly on available "nonscientific" data collected by recreational fishermen, one of the main stakeholder groups involved in NNF introduction and spread. This approach can easily be implemented for other NNF and may eventually allow the identification of areas of recurring first occurrences within a river drainage. These areas may be primary targets for close monitoring and environmental awareness campaigns directed at recreational fishermen, aiming at the prevention/ reduction of future introductions. Additionally, the obtained results highlight the need for urgent coordination at the international level due to the transnational nature of the 
Table 2. Detailed sources consulted for construction of $I$. punctatus invasion route on Guadiana river basin.

\begin{tabular}{|c|c|c|c|c|c|}
\hline \multirow{2}{*}{$\frac{\text { Source type }}{\text { Youtube }}$} & \multirow{2}{*}{$\begin{array}{l}\text { Year capture } \\
1983\end{array}$} & \multirow{2}{*}{$\begin{array}{l}\text { Local name } \\
\text { Castilseras dam }\end{array}$} & \multicolumn{2}{|c|}{ Location coordinates } & \multirow{2}{*}{$\begin{array}{l}\text { Source } \\
\text { https://www.youtube.com/watch?v=2Lyt8oL8jeQ }\end{array}$} \\
\hline & & & $38^{\circ} 44^{\prime} 14.70^{\prime \prime} \mathrm{N}$ & $4^{\circ} 47^{\prime} 48.47^{\prime \prime} \mathrm{W}$ & \\
\hline Literature & 1999 & Orellana dam & $39^{\circ} 0^{\prime} 2.84^{\prime \prime} \mathrm{N}$ & $5^{\circ} 28^{\prime} 3.01^{\prime \prime} \mathrm{W}$ & Pérez-Bote (2006) \\
\hline Literature & 1999 & Zújar dam & $38^{\circ} 55^{\prime} 45.07^{\prime \prime} \mathrm{N}$ & $5^{\circ} 26^{\prime} 44.24^{\prime \prime} \mathrm{W}$ & Pérez-Bote (2006) \\
\hline Forums & 2006 & La Serena dam & $38^{\circ} 55^{\prime} 38.83^{\prime \prime} \mathrm{N}$ & $5^{\circ} 19^{\prime} 52.16^{\prime \prime} \mathrm{W}$ & http://foro.carpamania.com \\
\hline Literature & 2006 & La Serena dam & $38^{\circ} 55^{\prime} 38.83^{\prime \prime} \mathrm{N}$ & $5^{\circ} 19^{\prime} 52.16^{\prime \prime} \mathrm{W}$ & Hermoso et al. (2008) \\
\hline Forums & 2007 & La Serena dam & $38^{\circ} 55^{\prime} 38.83^{\prime \prime} \mathrm{N}$ & $5^{\circ} 19^{\prime} 52.16^{\prime \prime} \mathrm{W}$ & http://foro.carpamania.com \\
\hline Forums & 2008 & Orellana dam & $39^{\circ} 0^{\prime} 2.84^{\prime \prime} \mathrm{N}$ & $5^{\circ} 28^{\prime} 3.01^{\prime \prime} \mathrm{W}$ & http://foro.carpamania.com \\
\hline Forums & 2008 & Zújar dam & $38^{\circ} 55^{\prime} 45.07^{\prime \prime} \mathrm{N}$ & $5^{\circ} 26^{\prime} 44.24^{\prime \prime} \mathrm{W}$ & http://www.passioncarp.es \\
\hline Forums & 2008 & La Serena dam & $38^{\circ} 55^{\prime} 38.83^{\prime \prime} \mathrm{N}$ & $5^{\circ} 19^{\prime} 52.16^{\prime \prime} \mathrm{W}$ & http://foro.carpamania.com \\
\hline Forums & 2008 & Orellana dam & $39^{\circ} 0^{\prime} 2.84^{\prime \prime} \mathrm{N}$ & $5^{\circ} 28^{\prime} 3.01^{\prime \prime} \mathrm{W}$ & http://www.passioncarp.es \\
\hline Forums & 2009 & La Serena dam & $38^{\circ} 55^{\prime} 38.83^{\prime \prime} \mathrm{N}$ & $5^{\circ} 19^{\prime} 52.16^{\prime \prime} \mathrm{W}$ & http://foro.carpamania.com \\
\hline Forums & 2009 & La Serena dam & $38^{\circ} 55^{\prime} 38.83^{\prime \prime} \mathrm{N}$ & $5^{\circ} 19^{\prime} 52.16^{\prime \prime} \mathrm{W}$ & http://www.passioncarp.es \\
\hline Forums & 2010 & García-Sola dam & $39^{\circ} 11^{\prime} 43.95^{\prime \prime} \mathrm{N}$ & $5^{\circ} 10^{\prime} 31.75^{\prime \prime} \mathrm{W}$ & http://foro.carpamania.com \\
\hline Forums & 2010 & Zújar dam & $38^{\circ} 55^{\prime} 45.07^{\prime \prime} \mathrm{N}$ & $5^{\circ} 26^{\prime} 44.24^{\prime \prime} \mathrm{W}$ & http://www.passioncarp.es \\
\hline Forums & 2010 & Zújar dam & $38^{\circ} 55^{\prime} 45.07^{\prime \prime} \mathrm{N}$ & $5^{\circ} 26^{\prime} 44.24^{\prime \prime} \mathrm{W}$ & http://www.passioncarp.es \\
\hline Forums & 2010 & La Serena dam & $38^{\circ} 55^{\prime} 38.83^{\prime \prime} \mathrm{N}$ & $5^{\circ} 19^{\prime} 52.16^{\prime \prime} \mathrm{W}$ & http://foro.carpamania.com \\
\hline Forums & 2011 & Zújar dam & $38^{\circ} 55^{\prime} 45.07^{\prime \prime} \mathrm{N}$ & $5^{\circ} 26^{\prime} 44.24^{\prime \prime} \mathrm{W}$ & http://foro.carpamania.com \\
\hline $\begin{array}{l}\text { Blogs and others } \\
\text { web sources }\end{array}$ & 2011 & Ajuda bridge & $38^{\circ} 46^{\prime} 34.07^{\prime \prime} \mathrm{N}$ & $7^{\circ} 10^{\prime} 18.24^{\prime \prime} \mathrm{W}$ & http://alandroalandia.blogspot.pt \\
\hline Youtube & 2011 & Zújar dam & $38^{\circ} 55^{\prime} 45.07^{\prime \prime} \mathrm{N}$ & $5^{\circ} 26^{\prime} 44.24^{\prime \prime} \mathrm{W}$ & https://www.youtube.com/watch?v=nWANI5yKQeY \\
\hline Forums & 2012 & Zújar dam & $38^{\circ} 55^{\prime} 45.07^{\prime \prime} \mathrm{N}$ & $5^{\circ} 26^{\prime} 44.24^{\prime \prime} \mathrm{W}$ & $\mathrm{http}: / /$ foro.carpamania.com \\
\hline Forums & 2012 & Juromenha & $38^{\circ} 44^{\prime} 12.24^{\prime \prime} \mathrm{N}$ & $7^{\circ} 14^{\prime} 15.58^{\prime \prime} \mathrm{W}$ & http://www.portugalpesca.com \\
\hline Forums & 2012 & La Serena dam & $38^{\circ} 55^{\prime} 38.83^{\prime \prime} \mathrm{N}$ & $5^{\circ} 19^{\prime} 52.16^{\prime \prime} \mathrm{W}$ & http://www.passioncarp.es \\
\hline Forums & 2012 & La Serena dam & $38^{\circ} 55^{\prime} 38.83^{\prime \prime} \mathrm{N}$ & $5^{\circ} 19^{\prime} 52.16^{\prime \prime} \mathrm{W}$ & http://foro.carpamania.com \\
\hline Forums & 2012 & La Serena dam & $38^{\circ} 55^{\prime} 38.83^{\prime \prime} \mathrm{N}$ & $5^{\circ} 19^{\prime} 52.16^{\prime \prime} \mathrm{W}$ & http://foro.carpamania.com \\
\hline $\begin{array}{l}\text { Blogs and others } \\
\text { web sources }\end{array}$ & 2012 & Zújar dam & $38^{\circ} 55^{\prime} 45.07^{\prime \prime} \mathrm{N}$ & $5^{\circ} 26^{\prime} 44.24^{\prime \prime} \mathrm{W}$ & http://www.todoslospecestodaslastecnicas.com \\
\hline $\begin{array}{l}\text { Blogs and others } \\
\text { web sources }\end{array}$ & 2012 & Juromenha & $38^{\circ} 44^{\prime} 12.24^{\prime \prime} \mathrm{N}$ & $7^{\circ} 14^{\prime} 15.58^{\prime \prime} \mathrm{W}$ & http://alandroalandia.blogspot.pt \\
\hline Youtube & 2012 & Castilseras dam & $38^{\circ} 44^{\prime} 14.70^{\prime \prime} \mathrm{N}$ & $4^{\circ} 47^{\prime} 48.47^{\prime \prime} \mathrm{W}$ & https://www.youtube.com/watch?v=2Lyt8oL8jeQ \\
\hline Youtube & 2012 & La Serena dam & $38^{\circ} 55^{\prime} 38.83^{\prime \prime} \mathrm{N}$ & $5^{\circ} 19^{\prime} 52.16^{\prime \prime} \mathrm{W}$ & https://www.youtube.com/watch?v=FNL5UwbMI34 \\
\hline Forums & 2013 & La Serena dam & $38^{\circ} 55^{\prime} 38.83^{\prime \prime} \mathrm{N}$ & $5^{\circ} 19^{\prime} 52.16^{\prime \prime} \mathrm{W}$ & http://foro.carpamania.com \\
\hline Forums & 2013 & La Serena dam & $38^{\circ} 55^{\prime} 38.83^{\prime \prime} \mathrm{N}$ & $5^{\circ} 19^{\prime} 52.16^{\prime \prime} \mathrm{W}$ & http://foro.carpamania.com \\
\hline $\begin{array}{l}\text { Blogs and others } \\
\text { web sources }\end{array}$ & 2013 & Zújar dam & $38^{\circ} 55^{\prime} 45.07^{\prime \prime} \mathrm{N}$ & $5^{\circ} 26^{\prime} 44.24^{\prime \prime} \mathrm{W}$ & http://lapescaenbadajoz.blogspot.pt \\
\hline Forums & 2014 & La Serena dam & $38^{\circ} 55^{\prime} 38.83^{\prime \prime} \mathrm{N}$ & $5^{\circ} 19^{\prime} 52.16^{\prime \prime} \mathrm{W}$ & http://www.passioncarp.es \\
\hline $\begin{array}{l}\text { Blogs and others } \\
\text { web sources }\end{array}$ & 2014 & La Colada dam & $38^{\circ} 31^{\prime} 34.04^{\prime \prime} \mathrm{N}$ & $5^{\circ} 0^{\prime} 17.13^{\prime \prime} \mathrm{W}$ & http://luciobass.blogspot.pt \\
\hline Youtube & 2014 & Castilseras dam & $38^{\circ} 44^{\prime} 14.70^{\prime \prime} \mathrm{N}$ & $4^{\circ} 47^{\prime} 48.47^{\prime \prime} \mathrm{W}$ & https://www.youtube.com/watch?v=LjNg4BYo-BE \\
\hline Forums & 2015 & Zújar dam & $38^{\circ} 55^{\prime} 45.07^{\prime \prime} \mathrm{N}$ & $5^{\circ} 26^{\prime} 44.24^{\prime \prime} \mathrm{W}$ & http://www.passioncarp.es \\
\hline Forums & 2015 & Mérida & $38^{\circ} 55^{\prime} 8.06^{\prime \prime} \mathrm{N}$ & $6^{\circ} 21^{\prime} 21.37^{\prime \prime} \mathrm{W}$ & http://foro.carpamania.com \\
\hline $\begin{array}{l}\text { Blogs and others } \\
\text { web sources }\end{array}$ & 2015 & Badajoz & $38^{\circ} 51^{\prime} 49.29^{\prime \prime} \mathrm{N}$ & $7^{\circ} 0^{\prime} 51.61^{\prime \prime} \mathrm{W}$ & http://amoscaporextremadura.blogspot.pt \\
\hline Forums & 2016 & Zújar dam & $38^{\circ} 55^{\prime} 45.07^{\prime \prime} \mathrm{N}$ & $5^{\circ} 26^{\prime} 44.24^{\prime \prime} \mathrm{W}$ & http://www.passioncarp.es \\
\hline Literature & 2016 & Alqueva dam & $38^{\circ} 11^{\prime} 57.89^{\prime \prime} \mathrm{N}$ & $7^{\circ} 29^{\prime} 47.93^{\prime \prime} \mathrm{W}$ & This work \\
\hline Literature & 2016 & Mértola & $37^{\circ} 38^{\prime} 36.40^{\prime \prime} \mathrm{N}$ & $7^{\circ} 39^{\prime} 11.20^{\prime \prime} \mathrm{W}$ & This work \\
\hline Youtube & 2016 & Orellana dam & $39^{\circ} 0^{\prime} 2.84^{\prime \prime} \mathrm{N}$ & $5^{\circ} 28^{\prime} 3.01^{\prime \prime} \mathrm{W}$ & https://www.youtube.com/watch?v=DGkipnhTg5s \\
\hline Youtube & 2016 & Zújar dam & $38^{\circ} 55^{\prime} 45.07^{\prime \prime} \mathrm{N}$ & $5^{\circ} 26^{\prime} 44.24^{\prime \prime} \mathrm{W}$ & https://www.youtube.com/watch?v=hTsvxsqcH7o \\
\hline
\end{tabular}

Iberian Peninsula river's watersheds, aiming particularly at the new European Union Alien Invasives legislation (EU regulation 2016/1141) and the recently published list of invasive species of concern.

Acknowledgements. We thank Mr. Paulo Mata Pinto for his help in Ictalurus punctatus capture in the Alqueva reservoir. This work was supported by the FRISK Project (Ref. PTDC/
AAG-MAA/0350/2014); strategic plan of MARE - Marine and Environmental Sciences Centre (UID/MAR/04292/2013) and by the MARE mini-grants project "Análise das rotas de dispersão de peixes invasores predadores na Península Ibérica". F. Banha and F. Ribeiro were supported by postdoctoral grants from MARE (MAR-04292). A. Veríssimo was funded by Fundação para a Ciência e Tecnologia (SFRH/BPD/ $77487 / 2011)$. 


\section{References}

Appelget J, Smith Jr. LL. 1951. The determination of age and rate of growth from vertebrae of the channel catfish, Ictalurus lacustris punctatus. Trans Am Fish Soc 80: 119-139.

Banha F, Anastácio PM. 2015. Live bait capture and crayfish trapping as potential vectors for freshwater invasive fauna. Limnologica 51: 63-69.

Banha F, Ilhéu M, Anastácio PM. 2015. Angling web forums as an additional tool for detection of new fish introductions: the first record of Perca fluviatilis in continental Portugal. Knowl Manag Aquat Ecosyst 416: 03.

Banha F, Gimeno I, Lanao M, Touya V, Durán C, Peribáñez MA, Anastácio PM. 2016. The role of waterfowl and fishing gear on zebra mussel larvae dispersal. Biol Invasions 18: 115-125.

Cannamela DA, Brader JDD, Johnson W. 1978. Feeding habits of catfishes in Barkley and Kentucky lakes. In: Proceedings of the Annual Conference of the Southeastern Association of Fish and Wildlife Agencies, vol. 32, pp. 686-691.

Dames HR, Coon TG, Robinson JW. 1989. Movements of channel and flathead catfish between the Missouri River and a tributary, Perche Creek. Trans Am Fish Soc 118: 670-679.

Doadrio I. 2001. Atlas y libro rojo de los peces continentales de Espana. Madrid, Spain: Dirección General de Conservación de la Naturaleza.

Elvira B, Almodóvar A. 2001. Freshwater fish introductions in Spain: facts and figures at the beginning of the 21st century. J Fish Biol 59: 323-331.

Filipe A, Marques T, Tiago P, Ribeiro F, Da Costa LM, Cowx I, Collares-Pereira M. 2004. Selection of priority areas for fish conservation in Guadiana River Basin, Iberian Peninsula. Conserv Biol 18: 189-200.

Filipe AF, Araujo MB, Doadrio I, Angermeier PL, Collares-Pereira MJ. 2009. Biogeography of Iberian freshwater fishes revisited: the roles of historical versus contemporary constraints. J Biogeogr 36: 2096-2110.

Filipe AF, Magalhães MF, Collares-Pereira MJ. 2010. Native and introduced fish species richness in Mediterranean streams: the role of multiple landscape influences. Divers Distrib 16: 773-785.

Gago J, Anastácio P, Gkenas C, Banha F, Ribeiro F. 2016. Spatial distribution patterns of the non-native European catfish, Silurus glanis, from multiple online sources - a case study for the River Tagus (Iberian Peninsula). Fish Manag Ecol 23: 503-509.

Goolsby JA, De Barro PJ, Makinson JR, Pemberton RW, Hartley DM, Frohlich DR, 2006. Matching the origin of an invasive weed for selection of a herbivore haplotype for a biological control programme. Mol Ecol 15: 287-297.

Gozlan R, Britton J, Cowx I, Copp G. 2010. Current knowledge on non-native freshwater fish introductions. $J$ Fish Biol 76: 751-786.

Hawkins JA, Nesler TP. 1991. Nonnative fishes of the Upper Colorado River Basin: an issue paper. Final Report of Colorado State University Larval Fish Laboratory to Upper Colorado River Endangered Fish Recovery Program, Denver, Colorado, USA.

Hermoso VH, Garrido FB, Marín JP. 2008. Spatial distribution of exotic fish species in the Guadiana river basin, with two new records. Limnetica 27: 189-194.

Hubbs C, Edwards RJ, Garrett GP. 2008. An annotated checklist of the freshwater fishes of Texas, with keys to identification of species, USA.

Hubley Jr. RC. 1963. Movement of tagged channel catfish in the upper Mississippi River. Trans Am Fish Soc 92: 165-168.

Leprieur F, Beauchard O, Blanchet S, Oberdorff T, Brosse S. 2008. Fish invasions in the world's river systems: when natural processes are blurred by human activities. PLoS Biol 6: e28.
Ligas A. 2008. First record of the channel catfish, Ictalurus punctatus (Rafinesque, 1818), in central Italian waters. $J$ Appl Ichthyol 24: 632-634.

López V, Franch N, Pou Q, Clavero M, Gaya N, Queral, JM. 2012. Atles dels peixos del delta de l'Ebre. Collecció tècnica, 3. Generalitat de Catalunya, Departament d'Agricultura, Ramaderia, Pesca i Medi Natural. Parc Natural del Delta de l'Ebre. 1a edició. Barcelona, Spain, $224 \mathrm{p}$.

Marsh PC, Brooks JE. 1989. Predation by ictalurid catfishes as a deterrent to re-establishment of hatchery-reared razorback suckers. Southwest Nat 34: 188-195.

Marta P, Bochechas J, Collares-Pereira MJ. 2001. Importance of recreational fisheries in the Guadiana River Basin in Portugal. Fish Manag Ecol 8: 345-354.

McCammon GW. 1956. A tagging experiment with channel catfish (Ictalurus punctatus) in the lower Colorado River. Calif Fish Game 42: 323-335.

Mehta SV, Haigh RG, Homans FR, Polasky S, Venette RC. 2007. Optimal detection and control strategies for invasive species management. Ecol Econ 61: 237-245.

Moyle P. 2002. Inland fishes of California. Berkeley, CA, USA: University of California Press.

Moyle PB, Light T. 1996. Biological invasions of fresh water: empirical rules and assembly theory. Biol Conserv 78: 149-161.

Olden J, Poff N. 2005. Long-term trends of native and non-native fish faunas in the American Southwest. Anim Biodivers Conserv 28: $75-89$.

Paruch W. 1986. Identification of Wisconsin catfishes (Ictaluridae): a key based on pectoral fin spines. Wis Acad Sci Arts Lett 74: $58-62$.

Pérez-Bote JL. 2006. Peces introducidos en Extremadura. Análisis histórico y tendencias de futuro. Rev Estud Extrem 62: 485-494.

Perry Jr. WG. 1969. Food habits of blue and channel catfish collected from a brackish-water habitat. Prog Fish Cult 31: 47-50.

Rabitsch W, Milasowszky N, Nehring S, Wiesner C, Wolter C, Essl F. 2013. The times are changing: temporal shifts in patterns of fish invasions in central European fresh waters. J Fish Biol 82: $17-33$.

Ribeiro F, Veríssimo A. 2014. Full westward expansion of Rutilus rutilus (Linnaeus, 1758) in the Iberian Peninsula. J Appl Ichthyol 30: $540-542$.

Ribeiro F, Chaves ML, Marques TA, da Costa LM. 2006. First record of Ameiurus melas (Siluriformes, Ictaluridae) in the Alqueva reservoir, Guadiana basin (Portugal). Cybium 30: 283-284.

Ribeiro F, Collares-Pereira MP, Moyle PB. 2009a. Non-native fish in the fresh waters of Portugal, Azores and Madeira Islands: a growing threat to aquatic biodiversity. Fish Manag Ecol 16: 255-264.

Ribeiro F, Gante HF, Sousa G, Filipe AF, Alves MJ, Magalhães MF. 2009b. New records, distribution and dispersal pathways of Sander lucioperca in Iberian freshwaters. Cybium 33: 255-256.

Ribeiro F, Rylková K, Moreno-Valcárcel R, Carrapato C, Kalous L. 2015. Prussian carp Carassius gibelio: a silent invader arriving to the Iberian Peninsula. Aquat Ecol 49: 99-104.

Sala OE, Chapin FS, Armesto JJ, Berlow E, Bloomfield J, Dirzo R, Huber-Sanwald E, Huenneke LF, Jackson RB, Kinzig A. 2000. Global biodiversity scenarios for the year 2100. Science 287: 1770-1774.

Savini D, Occhipinti-Ambrogi A, Marchini A, Tricarico E, Gherardi F, Olenin S, Gollasch S. 2010. The top 27 animal alien species introduced into Europe for aquaculture and related activities. $J \mathrm{Appl}$ Ichthyol 26: 1-7. 
Sax LJ, Gilmartin SK, Bryant AN. 2003. Assessing response rates and non response bias in web and paper surveys. Res High Educ 44: 409-432.

Simberloff D. 2001. Inadequate solutions for a global problem? Trends Ecol Evol 16: 323-324.

Sneed KE. 1951. A method for calculating the growth of channel catfish, Ictalurus lacustris punctatus. Trans Am Fish Soc 80: 174-183.

Tucker CS, Hargreaves JA. 2004. Biology and culture of channel catfish, vol. 34. San Diego, CA, USA: Elsevier Publishing Co.

Uzunova E, Zlatanova S. 2007. A review of the fish introductions in Bulgarian freshwaters. Acta Ichthyol Piscat 37: 55-61.

Venturelli PA, Hyder K, Skov C. 2017. Angler apps as a source of recreational fisheries data: opportunities, challenges and proposed standards. Fish Fish 18: 578-595.
Ward RD, Zemlak TS, Innes BH, Last PR, Hebert PD. 2005. DNA barcoding Australia's fish species. Philos Trans Royal Soc B 360: $1847-1857$.

Welcomme RL. 1988. International introductions of inland aquatic species. FAO Fisheries Technical Paper 213: 120.

Wong LL, Peatman E, Lu J, Kucuktas H, He S, Zhou C, Na-Nakorn U, Liu Z. 2011. DNA barcoding of catfish: species authentication and phylogenetic assessment. PLoS One 6: 17812.

Ziebell CD. 1973. Ultrasonic transmitters for tracking channel catfish. Prog Fish Cult 35: 28-32.

Zogaris S, Chatzinikolaou Y, Koutsikos N, Economou AN, Oiokonomou E, Michaelides G, Hadjisterikotis E, Beaumont WRC, Ferreira MT. 2012. Freshwater fish assemblages in Cyprus with emphases on the effects of dams. Acta Ichthyol. Piscat. 42: 165-175.

Cite this article as: Banha F, Veríssimo A, Ribeiro F, Anastácio PA. 2017. Forensic reconstruction of Ictalurus punctatus invasion routes using on-line fishermen records. Knowl. Manag. Aquat. Ecosyst., 418, 56. 